Doi: https://doi.org/10.31578/jebs.v6i2.239

\title{
Do Teachers' Qualifications and Experience Influence Academic Performance of Students in Basic Science in Junior Secondary Schools in Nigeria?
}

\author{
Daniel Idowu Oludipe * \\ Bimbola Dupe Oludipe **
}

\begin{abstract}
This study investigated the influence of teachers' qualification and experience on students' academic performance in basic science in junior secondary schools in Nigeria. The study was a descriptive survey type of research. Simple random sampling was used to select eight Junior Secondary Schools (J.S.S.) in Ogun East senatorial district of Ogun State. It included 18basic science teachers and 540 junior secondary school students. The data were collected using a questionnaire and basic science achievement test. The data collected were analysed using descriptive statistics, one-way analysis of variance and Pearson Product-Moment Correlation. The findings of this study revealed that most of the basic science teachers at the J.S.S. level were not trained as basic science teachers; science teachers' qualifications influenced students' academic performance in basic science; basic science teachers' years of teaching experience did not have a positive correlation with students' academic performance in basic science.
\end{abstract}

Keywords: Qualification, academic performance, problem solving

\section{Introduction}

Education is perhaps the largest and most costly of all the National undertakings in Nigeria nowadays. This is not surprising, since there is a general agreement that education is the most valuable resource in any nation and that it is the foundation of a nation's economic, social and political strength. Education is the cornerstone of any nation and has remained for some time a big industry in Nigeria (Taiwo, 2018). In recent years, there has been growing awareness that advancement in education depends largely on the qualifications and ability of teachers (Adeogun, 2001). Teachers are the most important single factor in the success of an educational enterprise (Aaronson, Barrow \& Sander, 2007; Harris \& Sass, 2008; Rivkin, Hanushek and Kain, 2005). Teachers, therefore, have a vital role to play in the development of a nation, especially in upbringing leaders and intellectuals of tomorrow who will sustain the nation's development (Taiwo, 2018). If one seeks the explanation of the rise of any nation, one will have to turn to schools and examine the calibre of their teachers. Therefore, it is not surprising that both the developed and the developing nations of the world are today asking questions about their teachers, their relevance and adequacy of their preparations. There has been much concern expressed in recent years about the apparent fall in standard of education in Nigeria, most especially at the secondary school level (Olagoke, 2018). This perhaps explains why Nigerian Government has moved from one system of educational structure to another in search of excellence in its educational products (Duze, 2011). The main causes for this fall in standard of education, according to Olagoke (2018), are low teacher/pupils ratio caused by the geometric progression in students'

\footnotetext{
* PhD, Tai Solarin College of Education, Ogun State, Nigeria

** PhD, Olabisi Onabanjo University, Ago-Iwoye, Ogun State, Nigeria

Corresponding Email: daniel.oludipe@gmail.com, bimbolaoludipe@yahoo.com
} 
population and lack of qualified teachers. This downward trend in Nigerian standard of education has become a thorn in the flesh for all science educators who sincerely want to see teachers as transforming elements and students as totally developed individuals capable of affecting technological change in society.

The first form of science a Nigerian child encounters in school is integrated science, at the junior secondary school level. This first form of science has changed to basic science due to educational reforms in Nigeria (FRN, 2007). The subject was introduced into the Nigerian secondary schools as a panacea for some of the problems bedevilling science especially at the junior level, most especially with the revised policy on education with emphasis on the acquisition of process skills (Bamidele and Adekola, 2017). The emphasis of the programme is on the development of the spirit of enquiry as opposed to rote learning, as well as the development of science process skills and scientific attitudes rather than accepting scientific facts as a dogma (Bamidele, 2014). According to the National Policy on Education (FGN, 2007), basic science is supposed to be presented in such a way that the child:

I. Gains the concept of fundamental unity of science (Physics, Chemistry and Biology);

II. Gains the communality of approach to problem-solving of scientific nature;

III. Gains an understanding of the role and function of science in everyday life and the world in which he/she lives.

From the above, basic science serves as the gateway to the study of single science subjects, which provides a solid foundation for the learning of the specialized scientific discipline like physics, chemistry and biology. Hence, a child who is not well-grounded in basic science at the junior secondary school level may see the core science subjects as bitter pills to swallow. Thus, students' poor performance in basic science at the junior secondary school level may lead to many junior secondary school students developing a negative attitude towards core science subjects at the senior secondary school level, which in turn will affect students' admission into tertiary institutions to study science and science-related courses. One is compelled to ask the extent to which integrated science departments have contributed to this present concern about the general fall in the standard of education in Nigeria. Professional science educators and a few qualified basic science teachers have severely criticized the teaching of basic science as ineffective and often handled by inexperienced or, at worst, unqualified teachers (Odetoyinbo, 2004; Olarewaju, 1987; Oludipe, 1997). The concern for basic science teachers' qualifications makes it necessary for this study to look into the qualifications of teachers teaching basic science at the junior secondary school level.

\section{Background to the Study}

Universities and colleges, apart from supplying professional graduates, also supply our secondary schools with graduate teachers without professional teaching qualifications (Odetoyinbo, 2004; Olarewaju, 1987). While one may concede academic excellence in subject areas to this set of teachers, the other essential pre-requisite for teaching, that is professionalism, is still lacking. In this era of need for teachers who are capable of directing and facilitating the changes that modern education involves, the basic science teachers should combine academic excellence with professional competence to be effective. A teacher who has no relevant training and qualification may not have been exposed to methods that make the teaching/learning process interesting and successful. We may not understand the use of some complicated equipment for teaching/learning process, therefore may not be able to communicate abstract ideas and concepts effectively without them. This definitely decreases the rate at which students understand subject matter. Recruiting adequately-qualified basic science teachers needs particular attention. It is one thing to have a school staffed with teachers, while it is another thing to have qualified teachers. For teaching to be meaningful 
and effective, there is a need for adequate supply of qualified teachers capable of transforming students. Without adequate supply of qualified basic science teachers to junior secondary schools, it will become difficult to attend to the academic needs of each of the students, especially where there is only one basic science teacher to three levels of classes of about ninety or more students at each level. When a teacher is unable to work as efficiently as he would have wanted to, there is a problem created in the teaching/learning process in which students are unable to perform maximally and may even feel they lack competence. Teachers also may become discouraged when students are not giving expected responses.

\section{Literature Review}

Merriam-Webster Dictionary defines 'qualification' as a special skill or type of experience or knowledge that makes someone suitable to do a particular job or activity (Aina, Olanipekun, \& Garuba 2015). Therefore, teachers' qualification is a particular skill or type of experience or knowledge someone possesses to make him or her able to teach effectively. Teachers' qualifications could, consequently, mean all the skills a teacher is required to teach well. Such skills include formal education, experience, subject matter knowledge, pedagogy studies, duration of training, certificate/license and professional development (Zuzovsky, 2009). Someone might have a teaching certificate at hand but without adequate knowledge of subject matter, this individual has no teaching qualifications yet. Similarly, someone without proper knowledge of pedagogy or someone who spent few years in training (Darling-Hammond, Berry \& Thoreson, 2001) without completing the required years does not possess teacher qualifications. Professional development and experience (Rice, 2003) also count for teachers' qualifications, as several studies have revealed (Helk, 2007). Qualification is one of the critical factors that drive students' academic performance (Hakielimu, 2011).

Eryilmaz and Laslan (1999) observed that one of the most important factors in the teaching process is teacher's qualification. The perspective of Ibrahim (2000) was that teachers' qualifications can go a long way to bring about students' higher academic achievement. Teachers' profession relates to competence in instruction and management of students and materials in the classroom (Hamilton-Ekeke, 2013). A qualified teacher is the one who holds a teaching certificate and/or is licensed by the state, owns at least a National Certificate in Education (NCE) and a bachelor's degree from a three- or four-year institution and is knowledgeable in his/her area of specialization (Musau \& Abere, 2015). However, Darling-Hammond (1998) defines a wellqualified teacher just as one who was fully certified and held the equivalent of a major in the field being taught. Teachers' qualifications are more than just holding a certificate of any institution. Zuzovsky (2009) in her study ties teachers' qualifications to seven indicators that are:

- $\quad$ Teachers' formal education;

- Teachers' education in the subject matter of teaching (in-field preparation);

- Teacher education in pedagogical studies;

- Duration of the preparation period;

- Certification and licensing status;

- Years of experience;

- Preparation in professional development activities.

Teachers' qualifications can be divided into two categories: personal qualities and certification. What qualifies someone to teach and that can influence students' academic performance are related to certain qualities teacher got in the classroom and 
was certificated at a particular period of his or her lifetime. The personal qualities are changing continuously in his or her lifetime. Degree certificates, formal education, and in-field preparation are not throughout the life of a teacher. Once a teacher obtains them, it is over for his or her lifetime. Teaching strategies, experience, professional development, motivation, and interaction are personal to the individual teacher and keep changing during the teacher's life. A teacher who has a bad teaching strategy today may not have it later. A teacher's experience today will not remain the same in a year to come, so will professional development. A teacher who is poor in motivating and interacting with students today may not remain the same or learn how to do it.

Some studies found that teachers' experience and educational qualifications significantly influenced students' academic achievement (Ankomah, Koomson, Bosu \& Oduro, 2005; Asikhia, 2010; Njeru and Orodho, 2003; Bamidele \& Adekola, 2017; Clotfelter, Ladd \& Vigdor, 2007; Kosgei, Mise, Odera \& Ayugi, 2013; Musau \& Migosi, 2015; Olaleye, 2011). When conducting research on factors contributing to underachievement of Zambian female students in O- Level physics examinations, Maguswi (2011) found that lack of qualified teachers of physics had a significant contribution. Moreover, a study conducted by Adaramola and Obomanu (2011) in Nigeria found that the lack of qualified teachers led to consistent poor performance of students in SMT subjects. However, studies held by other scholars found that teachers' professional qualifications and teaching experience are not significantly related to students' academic achievement (Buddin \& Zamarro, 2009; Kimani, Kara \& Njagi, 2013;Mbugua, Kibet, Muthaa and Reche, 2012; Musau and Abere, 2013; Rivkin et al., 2005). Akinsolu (2010) asserted that the availability of qualified teachers determined the performance of students in schools. On the contrary, Igwe (1990) investigated the influence of teacher's qualification in Kano county and reported that there is no significant relationship between teacher's qualification and student's performance. Huang and Moon (2009) state that teacher's qualification accounted for approximately 40 to 60 per cent of variance in the average of student's achievement in assessment. Seweje and Jegede (2005) noted that the ability of a teacher to teach is derived not only from one's academic background but is also based upon outstanding pedagogical skill acquired. Both Stronge, Ward, Tucker and Hindman (2007) and Kosgei, Mise, Odera \& Ayugi (2013) asserted that there is a positive correlation between teachers' experience and students' academic achievement.

\section{Statement of the Problem}

Basic science is the sound basis for studying single science subjects (physics, chemistry and biology) at the senior secondary school level (S.S.S.). Students must obtain credit pass in basic science before they can offer the single science subjects at the S.S.S. level. However, students' failure rate in basic science at the junior secondary school level (J.S.S.) has been reducing the numbers of students eligible to study single science subjects at the S.S.S. level. Teacher characteristics have been identified to play a significant role in student's academic performance. It is hoped that if qualified teachers, who went through pedagogical training in basic science education, are the ones teaching the subject at the J.S.S. level, basic science would be an interesting subject to learn by students. Hence, this study examined the impact of teacher's qualifications on the academic performance of students in basic science in Ogun state, South-West Nigeria.

\section{Objectives of the Study}

The main objectives of this study were:

1. To examine the qualifications of teachers teaching basic science at the junior secondary school (J.S.S.) level.

2. To find out if the type of training basic science teachers received would affect effective teaching of integrated science.

3. To examine the years of teaching experience of basic science teachers. 
4. To find out the academic achievement of students taught by qualified basic science teachers and those taught by less qualified basic science teachers.

5. To find out if there is a correlation between basic science teachers' years of teaching experience and students' academic achievement.

\section{Hypotheses}

The following hypotheses were formulated and tested:

Ho 1 : There is no significant difference in the academic performance of J.S.S. students in basic science between those taught by unqualified basic science teachers and those taught by qualified basic science teachers.

$\mathrm{Ho}_{2}$ : There is no significant correlation between basic science teachers' years of teaching experience and students' academic performance in basic science.

\section{Methodology}

\section{Research Design}

This study is a descriptive survey type of research. It sought to find out the influence of teachers' qualifications and experience on students' academic performance in basic science and also sought to find out the degree of relationship between the independent variables (teachers' qualifications and experience) and the dependent variable (students' academic performance in basic science at the J.S.S. level.

\section{Population}

The population for this study was the Junior Secondary School III students and their teachers in the fifty junior secondary public schools in the nine local government areas of Ogun East senatorial district, Ogun state, Nigeria.

\section{Sample and Sampling Procedure}

Simple random sampling technique was used to select eighteen out of the fifty junior secondary schools, i.e. two J.S.S. were randomly selected from the total number of J.S.S. in each of the nine local government areas. The researcher preferred simple random sampling because it gave equal chance for all junior secondary schools in the Ogun East senatorial district to be selected. Eighteen integrated science teachers, including 13 male and 5 female teachers, from the selected schools were purposively included in the study. This gave a total of 540 sampled students. The researcher targeted only the J.S.S. students because they had been through all the levels (forms one to three), and had adequate exposure to the contents of basic science.

\section{Instrumentation}

The study employed the following instruments:

1. Basic Science Teacher's Questionnaire (BSTQ): The BSTQ was developed by the researcher to elicit responses from basic science teachers. The questionnaire sought demographic information such as sex, highest educational qualification, area of specialization and length of years in service. 
2. Basic Science Achievement Test (BSAT): The BSAT was made up of 40 objective questions selected from the previous Junior Secondary Certificate Examination (JSCE) questions based on the topics treated during the study.

\section{Validity and Reliability of the Instruments}

The basic science multiple-choice performance test questions were selected from the previous Junior Secondary Certificate Examination (JSCE) questions. The JSSCE questions are standardized in nature because they have been field-validated by experienced test and measurement experts in the state ministry of education. Moderating Committee edited and selected good items. Thereafter, the researcher subjected it to test-retest analysis of two weeks interval on a pilot sample of 30 basic science J.S.S. students to establish the reliability of the instrument. The reliability coefficient yielded 0.76 indicating that the instrument is reliable. Basic Science Teachers' Questionnaire (BSTQ) was meant to get responses from basic science teachers on their competencies to teach basic science effectively. There were two sections in the questionnaire; section A sought for demographic data of teachers (highest educational qualification, area of specialization and length of years in service); while section B contained six items, participants responded to each of the 6 statements by selecting one of the following responses: agree, disagree, undecided. The BSTQ was given to experts in the field of curriculum studies to establish the content and face validity. They read through and made necessary corrections which were then taken into consideration in re-working the questionnaire. The BSTQ was further subjected to a reliability test, using thirty students who did not participate in the study. Cronbach Alpha were computed to determine the reliabilities of scores obtained in this context. The BSTQ yielded an internal consistency reliability of 0.79

\section{Procedure}

There were three phases of data collection. These were the pretest - the first week, treatment - six weeks, and the post-test - the last of the eight weeks. Three periods of 40 minutes each were spent each week for the six weeks during the second term of 2017/2018 academic session. There was no alteration on the time-table allocated for basic science by the school, i.e. the periods were in line with the schools' time-tables. Before exposing the students to teaching, the BSAT was administered as pre-test. The achievement post-test was administered within the week after the completion of the treatment; this was to minimize the maturation effect, by giving the students the same forty-item multiple choice test that was used for the pretests. The BSTQ was administered to the basic science teachers immediately after the administration of the post-test to students.

\section{Data Analysis}

Data collected was analysed using descriptive statistics, One-way Analysis Of Variance (ANOVA) and Pearson Product-Moment Correlation. Computations for the afore-mentioned methods of data analysis were done using SPSS 16.00 Statistical Package.

\section{Results}

Table 1: Certificates and areas of specialization of basic science teachers

\begin{tabular}{|l|l|l|l|l|}
\hline S/N & Certificate & Specialisation & Number & Percentage \\
\hline 1 & B.Ed. & Int. Science & 4 & 22.22 \\
\hline
\end{tabular}




\begin{tabular}{|l|l|l|l|l|}
\hline 2 & B.Ed. & Sciences & 4 & 22.22 \\
\hline 3 & B.Sc. & Sciences & 6 & 33.33 \\
\hline 4 & M.Sc. & Sciences & 3 & 16.67 \\
\hline 5 & M.Ed. & Science & 1 & 5.56 \\
\hline Total & & & 18 & 100 \\
\hline
\end{tabular}

Table 1 above reveals the certificates and areas of specialization of teachers teaching basic science at the sampled junior secondary schools.

Table 2: Basic science teachers' years of teaching experience

\begin{tabular}{|c|c|c|}
\hline Teachers & Qualification & Years of experience \\
\hline A & B.Ed. (Int. Science) & 5 \\
\hline B & B.Ed. (Physics) & 8 \\
\hline C & B.Ed. (Int. Science) & 20 \\
\hline$D$ & B.Ed. (Chemistry) & 12 \\
\hline$E$ & B.Sc. (Physics) & 5 \\
\hline $\mathrm{F}$ & B.Ed. (Int. Science) & 10 \\
\hline G & B.Sc. (Biochemistry) & 5 \\
\hline$H$ & B.Ed. (Biology) & 20 \\
\hline 1 & B.Sc. (Biology & 5 \\
\hline J & B.Ed. (Int. Science) & 15 \\
\hline K & B.Sc. (Chemistry) & 15 \\
\hline L & M.Sc. (Biochemistry) & 6 \\
\hline
\end{tabular}




\begin{tabular}{|l|l|l|}
\hline$M$ & B.Sc. (Biochemistry) & 15 \\
\hline$N$ & B.Ed. (Biology) & 22 \\
\hline $\mathrm{O}$ & M.Ed. (Biology) & 20 \\
\hline $\mathrm{P}$ & B.Sc. (Chemistry) & 15 \\
\hline $\mathrm{Q}$ & M.Sc. (Biology) & 12 \\
\hline R & M.Sc. (Biology) & 15 \\
\hline
\end{tabular}

Table 2 above reveals the sampled teachers' qualifications with their corresponding years of teaching experience. The lowest year of teaching experience was five years, while the highest was twenty-two years.

Table 3: Basic science teachers' responses to questions on basic science teaching competency

\begin{tabular}{|c|c|c|c|}
\hline Items & Agree & Disagree & Undecided \\
\hline $\begin{array}{l}\text { You are aware of the objectives of teaching basic } \\
\text { science. }\end{array}$ & $04(22.22)$ & $14(77.78)$ & - \\
\hline $\begin{array}{l}\text { You are aware of the philosophy of teaching basic } \\
\text { science. }\end{array}$ & $04(22.22)$ & $14(77.78)$ & - \\
\hline $\begin{array}{l}\text { You are aware of the methods of teaching basic } \\
\text { science. }\end{array}$ & $04(22.22)$ & $14(77.78)$ & - \\
\hline $\begin{array}{l}\text { You are aware of the evaluation methods of basic } \\
\text { science. }\end{array}$ & 09(50) & 09(50) & - \\
\hline $\begin{array}{l}\text { You are aware of the improvisation techniques in } \\
\text { basic science }\end{array}$ & 09(50) & 09(50) & - \\
\hline $\begin{array}{l}\text { You have attended seminar, workshop or in- } \\
\text { service training on basic science before }\end{array}$ & - & $18(100)$ & - \\
\hline You can teach all the topics in basic science & $04(22.22)$ & $14(77.78)$ & \\
\hline
\end{tabular}




\section{Numbers in brackets are in percentages.}

Table 3 above reveals basic science teachers' responses to various questions on their competencies to teach basic science.

Table 4: Descriptive analysis of students' mean scores in line with teachers' qualifications

\begin{tabular}{|c|c|c|c|c|c|c|c|c|}
\hline & & & & & 95\% Confiden & erval for Mean & & \\
\hline & $N$ & Mean & $\begin{array}{l}\text { Deviati } \\
\text { on }\end{array}$ & Std. Error & Lower Bound & $\begin{array}{l}\text { Upper } \\
\text { Bound }\end{array}$ & Minimum & Maximum \\
\hline B.Edlnt.Sc & 120 & 31.02 & 2.253 & .206 & 30.61 & 31.42 & 25 & 38 \\
\hline B.EdScience & 120 & 19.08 & 1.373 & .125 & 18.83 & 19.32 & 12 & 20 \\
\hline B.Sc & 180 & 10.84 & 1.094 & .082 & 10.68 & 11.00 & 1 & 12 \\
\hline M.Sc, & 90 & 10.82 & .842 & .089 & 10.65 & 11.00 & 10 & 12 \\
\hline M.EdScience & 30 & 18.70 & 1.643 & .300 & 18.09 & 19.31 & 15 & 20 \\
\hline Total & 540 & 17.59 & 8.109 & .349 & 16.90 & 18.27 & 1 & 38 \\
\hline
\end{tabular}

In table 4 above it is revealed that students taught by the qualified basic science teachers had the highest mean score (31.02) and standard deviation (2.253), followed by those taught by professional teachers (B.Ed. Science and M.Ed. Science) who were not trained as basic science teachers, with mean scores of (19.08) \& (18.70) and standard deviations (1.373) \& (1.643) respectively. The lowest mean scores and standard deviation were ascribed to students taught by the untrained teachers/unqualified basic science teachers (B.Sc. and M.Sc.) with mean scores of (10.84) \& (10.82) and standard deviation (1.094) \& (.842) respectively. 
Table 5: ONE-WAY ANOVA of students' mean scores according to basic science teachers' qualifications.

\begin{tabular}{|c|c|c|c|c|c|}
\hline & Sum of Squares & $d f$ & Mean Square & $F$ & Sig. \\
\hline Between Groups & 34260.834 & 4 & 8565.209 & 3.870 & .000 \\
\hline Within Groups & 1184.075 & 535 & 2.213 & & \\
\hline Total & 35444.909 & 539 & & & \\
\hline
\end{tabular}

p significant at $<0.05$.

$\mathrm{Ho}_{1}$ There is no significant difference in the academic performance of J.S.S. students in basic science between those taught by unqualified basic science teachers and those taught by qualified basic science teachers.

Table 5 reveals that there is a significant difference in the mean scores of students taught by qualified basic science teachers and those taught by unqualified basic science teachers $\left(\mathrm{F}_{(4,535)}=.000\right.$, statistically significant). Hence, hypothesis 1 is not accepted.

Table 6: Descriptive analysis of students' mean scores in line with teachers' experience

\begin{tabular}{|c|c|c|c|c|c|c|c|c|}
\hline & \multirow[b]{2}{*}{$\mathrm{N}$} & \multirow[b]{2}{*}{ Mean } & \multirow{2}{*}{$\begin{array}{l}\text { Std. } \\
\text { Deviation }\end{array}$} & \multirow[b]{2}{*}{ Std. Error } & \multicolumn{2}{|c|}{ 95\% Confidence Interval for Mean } & \multirow[b]{2}{*}{ Minimum } & \multirow[b]{2}{*}{ Maximum } \\
\hline & & & & & Lower Bound & Upper Bound & & \\
\hline 5 Years & 80 & 17.72 & 8.702 & .973 & 15.79 & 19.66 & 10 & 35 \\
\hline 6 Years & 63 & 18.49 & 9.546 & 1.203 & 16.09 & 20.90 & 2 & 33 \\
\hline 8Years & 75 & 19.13 & 8.899 & 1.028 & 17.09 & 21.18 & 10 & 33 \\
\hline 10Years & 68 & 16.85 & 7.827 & .949 & 14.96 & 18.75 & 10 & 37 \\
\hline 12Years & 68 & 17.99 & 7.544 & .915 & 16.16 & 19.81 & 11 & 37 \\
\hline 15Years & 67 & 17.54 & 7.987 & .976 & 15.59 & 19.49 & 10 & 37 \\
\hline
\end{tabular}




\begin{tabular}{|c|c|c|c|c|c|c|c|c|}
\hline & \multirow[b]{2}{*}{$\mathrm{N}$} & \multirow[b]{2}{*}{ Mean } & \multirow{2}{*}{$\begin{array}{l}\text { Std. } \\
\text { Deviation }\end{array}$} & \multirow[b]{2}{*}{ Std. Error } & \multicolumn{2}{|c|}{ 95\% Confidence Interval for Mean } & \multirow[b]{2}{*}{ Minimum } & \multirow[b]{2}{*}{ Maximum } \\
\hline & & & & & Lower Bound & Upper Bound & & \\
\hline 5Years & 80 & 17.72 & 8.702 & .973 & 15.79 & 19.66 & 10 & 35 \\
\hline 20Years & 60 & 17.22 & 7.069 & .913 & 15.39 & 19.04 & 10 & 32 \\
\hline 22Years & 59 & 15.15 & 5.765 & .751 & 13.65 & 16.65 & 10 & 30 \\
\hline Total & 540 & 17.57 & 8.074 & .347 & 16.89 & 18.25 & 2 & 37 \\
\hline
\end{tabular}

Table 6 above reveals that basic science teachers' years of teaching experience did not correlate with students' academic performance. Interestingly, basic science teachers with 5, 6 and 8 years teaching experience respectively had slightly higher mean scores and standard deviations scores than the basic science teachers with 10-22 years teaching experience.

$\mathrm{Ho}_{2}$ : There is no significant correlation between basic science teachers' years of teaching experience and students' academic performance in basic science.

Table 7: Pearson correlation between teachers' years of teaching experience and students' academic performance

\begin{tabular}{|l|l|l|l|}
\hline & & score & experience \\
\hline score & Pearson Correlation & 1 & $-.089^{*}$ \\
\cline { 2 - 4 } & Sig. (2-tailed) & & .039 \\
& $\mathrm{~N}$ & 540 & 540 \\
\hline experience & Pearson Correlation & $-.089^{*}$ & 1 \\
& Sig. (2-tailed) & .039 & 540 \\
\hline
\end{tabular}

*. Correlation is significant at the 0.05 level (2-tailed).

To examine the relationship between basic science teachers' years of teaching experience and students' academic performance, Pearson Product-Moment Correlation was used. According to the result in table 7, basic science teachers' years of teaching experience and students' academic performance were not significantly correlated, $-.089(538)=.039, p>0.05$. According to the finding, there was no positive interaction between basic science teachers' years of teaching experience and students' academic performance. Hypothesis 2 is accepted. 


\section{Discussion}

Table 1 reveals that basic science teachers at the sampled J.S.S. level were mostly holders of Bachelor degrees in education and sciences, and Master's degrees in education and sciences. Nine of the eighteen basic science teachers were professional teachers, i.e. they underwent pedagogical training as teachers; nine were not professional teachers. In all the eighteen schools in the study only four out of the eighteen teachers were trained as basic science teachers. Four of the remaining fourteen teachers had their bachelor degrees in education in biology, chemistry and physics respectively; six had their bachelor degrees in sciences - biology, chemistry, physics, and biochemistry; three had their Master's degrees in biology and chemistry; while one had her Master's degree in science education (biology). This points to the fact that there is shortage of trained basic science teachers in the sampled schools, and by extension across the junior secondary schools in Ogun state.

Table 2 revealed that the lowest number of basic science teachers' work experience was five years, while the highest was twenty-two years. A teacher's years of experience is one of the teachers' qualification indicators that is believed to be a significant determinant of students' academic performance. However, there is the need for caution in Nigeria about experience. Many teachers may have been in the teaching profession for over twenty years without having properly developed himself or herself for years. This category of teachers may not be able to cope with the new trends in education. The subject curriculum is changing almost every year as the whole world is changing. The years of work experience of an unqualified basic science teacher do not necessarily increase their qualification.

Table 3 revealed that competencies of basic science teachers in teaching basic science are affected by their certificates and the type of training they have received. A teacher who was not trained specifically as a basic science teacher would surely be unaware of the objectives, philosophy and methods of teaching basic science. Hence, such teachers will not be competent to teach basic science effectively. That was why only the four trained basic science teachers agreed that they were aware of the objectives, philosophy and methods of teaching basic science; while the remaining fourteen teachers, including the five professional teachers, disagreed. Talking about the awareness of evaluation methods and improvisation techniques in basics science, all the nine professional teachers agreed that they were aware of the evaluation methods and improvisation techniques in basic science; while the remaining nine non-professional teachers disagreed. This is not surprising because all science teachers were offered the same courses on the evaluation and improvisation techniques in sciences during their course of studies. A teacher who did not offer courses in evaluation and improvisation techniques, like the nine non-professional basic science teachers under study, would surely be unaware of how to handle evaluation and improvisation in basic science. Interestingly, the qualified basic science teachers, the trained teachers and the untrained teachers all disagreed that they had attended seminars, workshops or in-service training to update their knowledge and competencies on basic science. Attending seminars, workshops or in-service training is professional development which develops an individual skill, knowledge, expertise and other characteristics as a teacher (OECD, 2009). It is a conscious and systematic step to ensure teachers' upgrading and continuous self-improvement (Oluremi, 2013). Professional development is critical to the retention and improvement of any teacher in the classroom (American Association of Physics Teachers, 2009). Hence, the responses of the sampled basic science teachers not having attended any professional development programs are not encouraging at all. This will surely have a negative effect on students' academic performance, since professional development is related positively to students' achievement. Expectedly, only the four trained basic science teachers agreed that they could teach all the topics in basic science, while the remaining fourteen teachers (trained 
and untrained) disagreed that they could teach all the topics in basic science. Basic science comprises earth science, space science, life science, etc. Hence, any teacher who was not trained specifically as a basic science teacher would not be able to handle basic science contents. That is why in most junior secondary schools, where there are shortage of qualified basic science teachers, most of the basic science topics in the schemes of works outside the areas of specialisation of this set of unqualified teachers are not always covered. This has been having a negative effect on the teaching and learning of basic science at the J.S.S. level.

The results in tables 4 and 5 revealed that there was a significant difference in students' academic performance in basic science between the students taught by the qualified basic science teachers and those taught by the unqualified basic science teachers. This finding is in line with the findings of Adaramola and Obomanu, 2011; Akinsolu, 2010; Ankomah et al., 2005; Asikhia, 2010; Bamidele and Adekola, 2017Clotfelter et al., 2007; Kosgei et al., 2013; Njeru and Orodho, 2003; Maguswi, 2011; Musau \& Migosi, 2015; Olaleye, 2011. They all found in their studies that educational qualifications of teachers significantly influenced students' academic achievement and that students taught by qualified teachers performed better in achievement tests than students taught by unqualified teachers. However, this finding contradicts the findings of Buddin and Zamarro, 2009; Igwe, 1990; Kimani et al., 2013; Mbugua et al., 2012; Musau et al., 2013; Rivkin et al., 2005. They all found that teachers' professional qualifications were not significantly related to students' academic achievement. They were of the opinion that educational qualifications of teachers did not significantly influence students' academic achievement.

The results in tables 6 and 7 indicate that there was no positive interaction between basic science teachers' years of teaching experience and students' academic performance in basic science. This finding is in line with the findings of Buddin and Zamarro, 2009; Kimani et al., 2013; Mbugua et al., 2012; Musau et al., 2013; and Rivkin et al., 2005; they all asserted that teachers' years of teaching experiences were not significantly related to students' academic achievement. This is an interesting finding because it is believed that many teachers may have been in the teaching profession for over twenty years without having properly developed themselves for years. This category of teachers may not be able to cope with the new trends in education. The subject curriculum is changing almost every year as the whole world is changing due to technology changes. However, this finding contradicts the findings of Adaramola et. al., 2011; Agharuwhe, 2013; Ankomah et al., 2005; Asikhia, 2010; Bamidele and Adekola, 2017; Clotfelter et al., 2007; Kosgei et al., 2013;Maguswi, 2011; Njeru and Orodho, 2003; Musau \& Migosi, 2015; Olaleye, 2011; Stroge et al., 2007; They all found that teachers' years of teaching experiences were significantly related to students' academic achievement. This is a pointer to the fact that teachers with more years of teaching experiences will always draw from their wealth of experience to solve many of the students' learning problems.

\section{Conclusion}

This study examined the impact of basic science teacher's qualification on students' academic performance in basic science. Given the findings of this study, it can be concluded that basic science teacher's academic qualifications positively affect student's academic performance in basic science. This implies that basic science can only be taught effectively by a professionally trained teacher, who had acquired pedagogical skills in teaching in basic science. The study also revealed that teacher's years of teaching experience did not play a significant role in teaching/learning process. These are remarkable results, they call for further studies with wider samples within Nigeria and cross-cultural studies across the world. Results of such studies will make it possible for a more generalised picture to be established.

\section{Recommendations}

Based on the findings of this study, the following recommendations were made: 
1. Many of untrained basic science teachers should be sent for in-service training, seminars and workshops to update their knowledge competence on the teaching of basic science.

2. All the science education students, at both colleges of education and university levels, should be offered basic science as a minor teaching subject in their first and second years respectively.

3. Basic science education programmes (in-service and pre-service) should include the following drills on:

- the content of basic science

- appropriate use of language of instruction

- the application of methods of teaching

- improvisation techniques

- course evaluation techniques.

\section{Implication}

This study has important contributions and high implications for the educational practices in Nigeria. This study revealed that teachers' qualifications have a serious implication on students' academic performance. Hence, a qualified teacher is crucial in any educational system and that is why it is expedient to make sure that every teacher is academically and professionally qualified. 


\section{References}

Aaronson, D., Barrow, L., \& Sander, W. (2007). Teachers and student achievement in the Chicago public high schools. Journal of Labor Economics, 25 (1), 95-135

Adaramola, M.O. \& Obomanu, B. J. (2011). Factors related to underachievement in science, technology and mathematics education (STME) in secondary schools in rivers state, Nigeria. World Journal of Education, 1(1), 102-109.

Adeogun A.A. (2001). The principal and the financial management of public secondary schools in Osun State. Journal of Educational System and Development, 5(1), 1 - 10.

Agharuwhe, A. A. (2013). Effects of Teachers' Effectiveness on Students' Academic Performance in Public Secondary Schools; Delta State - Nigeria. Journal of Educational and Social Research, 3 (3), 105-111.

Aina, J.K., Olanipekun, S.S., \& Garuba, I.A. (2015). Teachers' effectiveness and its influence on student learning. Advances in Social Sciences Research Journal, 2(4), 88-95.

American Association of Physics Teachers (AAPT, 2009). AAPT 2009 Winter Meeting. Chicago: Illinois. Retrieved from: https://www.aapt.org/Conferences/WM2009/upload/program_final2.pdf

Akinsolu, A. O. (2010). Teachers and students' academic performance in Nigerian secondary schools: Implication for planning. Florida Journal of Educational Administration \& Policy 3(2), 86 - 103

Ankomah, Y., Koomson, J., Bosu, R., \& Oduro, G.K. (2005). Implementing Quality Education in Low Income Countries. Institute for Educational Planning \& Administration (IEPA). Cape Coast, Ghana: University of Cape Coast.

Asikhia, O.A. (2010). Students and teachers' perception of the causes of poor academic performance in Ogun state secondary schools. European Journal of Social Sciences, 13(2), 229-242.

Bamidele, A.D. (2014). Effects of peer-led guided inquiry and class-wide peer tutoring instructional strategies on senior secondary school students' performance and practical skills in chemistry. An unpublished PhD thesis, Ibadan: University of Ibadan.

Bamidele, A.D. \& Adekola, F.F. (2017). Effects of teacher's qualifications and teaching experience on students' academic achievement in basic science in junior secondary school. International Journal of Education and Evaluation, 3(2), 1-9.

Buddin, R.J. \& Zamarro, G. (2009). Teacher qualifications and student achievement in urban elementary schools. Journal of Urban Economics, 66(2), 103-115.

Clotfelter, C.T., Ladd, H.F., \& Vigdor, J.L. (2007). Teachers' Credentials and Students' Achievement in High School: A Cross-Subject Analysis with Student Fixed Effects. Working Paper II, Washington DC: Urban Institute, National Center for Analysis of Longitudinal Data in Education Research

Darling-Hammond, L. (1998). Teacher and teaching: Testing policy hypothesis from a National Commission report. Educational Researcher 27 (1), 57 - 77.

Darling-Hammond, L., Berry, B. \& Thoreson, A. (2001). Does teacher certification matter? Evaluating the evidence. Educational Evaluation and Policy Analysis, 23(1), 57-77.

Duze, C.O. (2011). Falling standard in Nigeria: Traceable to proper skills acquisition in schools? International Research Journals, 2 (1), 803-808. 
Eryilmaz, A. \& Laslan, H. (1999). Determining and evaluating ideal physics teacher's characteristics. Journal of Education, 16(17), 53-60.

Federal Republic of Nigeria (2007). Nigeria National Policy on Education (Revised Edition). NERC. Yaba Lagos.

Hakielimu (2011). Are our Teachers Qualified and Motivated to Teach? A research report on teachers' qualifications, motivation and commitment to teach and their implications on quality education. Retrieved April, 7, 2020 from http://hakielimu.org/files/publications/Are\%200ur\%20Teacher\%20Motivated\%20and\%20Qualified\%20to\%20Teach.pdf

Hamilton-Ekeke, J. (2013). Conceptual framework of teachers' competence in relation to students' academic achievement. International Journal of Networks and Systems, 2(3), 15-20.

Harris, D.N. \& Sass, T.R. (2008). Teacher Training, Teacher Quality and Student Achievement. CALDER working paper 3. Washington, D. C.: Urban Institute.

Helk, R.H. (2007). Examining the Relationship between Teacher Quality as an Organizational Property of Schools and Students' Achievement and Growth Rates. Educational Administration Quarterly,43(4), 399-432.Ibrahim, A. (2000). Evaluating the pedagogical competence of junior secondary school Integrated Science teachers'. 40th STAN Annual Conference Proceedings, 138-142.

Huang, F.L. \& Moon, T.R. (2009). Is experience the best teacher? A multilevel analysis of teacher characteristics and student achievement in low performing schools. Educational Assessment, Evaluation and Accountability, 21, 209 - 234.

Ibrahim, A. (2000). Evaluating the pedagogical competence of junior secondary school Integrated Science teachers'. 40th STAN Annual Conference Proceedings, 138-142.

Igwe, D.O. (1990). Science teacher qualification and students performance in secondary schools in Kano state. Journal of Science Teacher Association of Nigeria, 26(2), 24 - 51.

Kimani, G.N., Kara, A.M., \& Njagi, L.W. (2013). Teacher factors influencing students'academic achievement in secondary schools in Nyandarua county, Kenya. International Journal of Education Research, 1(3), 1-14.

Kosgei, A., Mise, J.K., Odera, O. \& Ayugi, M.E. (2013). Influence of teacher characteristics on students' academic achievement among secondary schools. Journal of Education and Practice 4 (3), 76 - 82.

Maguswi, B.V. (2011). Factors contributing to under achievement of Zambian female Students in O-level physics examinations. A case of selected high Schools in Central Province. A Masters' Thesis. Lusaka: University of Zambia.

Mbugua, Z.K., Kibet, K., Muthaa, G.M., Reche, G.N. (2012). Factors contributing to students' performance in mathematics at Kenya Certificate of Secondary Education: A case of Baringo county, Kenya. American Journal of Contemporary Research, 2(6), 87-91.

Musau, L.M. \& Abere, M.J. (2013). Determinants of girls' performance in science, mathematics and technology subjects in public secondary schools in Kenya. International Journal of Educational Administration Policy Studies, 5 (3), 33-42.

Musau, L.M. \& Migosi, J. A. (2015). Teacher qualification and students' academic performance in science, mathematics and technology subjects in Kenya. International Journal of Educational Administration and Policy Studies, 7(3), 83-89.

Njeru, E.H.N. \& Orodho, J.A. (2003). Access and Participation in Kenya. Nairobi: Institute of Policy Analysis and Research. 
Odetoyinbo, B.B. (2004). Teacher and student factors as correlates of achievement in integrated science. Journal of the Science Teachers Association of Nigeria (JSTAN), 39(1 \& 2), 17-22.

OECD (2009). Organisation for International Cooperation and Development Teaching and Learning International Survey (Talis). Paris: OECD. Retrieved from http://www.oecd.org/education/school/50456114.pdf

Olagoke, C.O. (2018). Teacher education as the last resort for students' enrolment into tertiary institutions: A Call for the fall in educational standard in South-Western Nigeria. A Paper Presented at the 9th National Conference of Colleges of Education Academic Staff Union, held at Adeyemi College of Education, Ondo State, Nigeria, 110-118

Olaleye, F.O. (2011). Teachers' characteristics as predictor of academic performance of students in secondary schools in Osun state -Nigeria. European Journal of Educational Studies, 3(3), 505 - 511.

Olarewaju, A.O. (1987). Some problems identified in implementing the core curriculum for integrated science. JSTAN, 25(2), 6167.

Oludipe, D.I. (1997). Causes and solutions of the negative attitude of students towards integrated science. Journal of Science Education, 2(1), 75-81.

Oluremi, O.F. (2013). Enhancing educational effectiveness in Nigeria through teachers' professional development. European Scientific Journal, 9(28), 422-431.

Rice, J.K. (2003). Teacher Quality: Understanding the Effectiveness of Teacher Attributes. Retrieved from http://www.amazon.com/Teacher-Quality-Understanding-Effectiveness-Attributes/dp/1932066063.

Rivkin, S.G., Hanushek, E.A., \& Kain, J.F. (2005). Teachers, schools and academic achievement. Econometrica, 73(2), 417-458.

Seweje, R.O., \& Jegede, S.A. (2005). Science Education and Science Teaching Methods. Lagos: Atlantic Association.

Stronge, J.H., Ward, T.J., Tucker, P.D. \& Hindman, J.L. (2007). What is relationship between teacher quality and student achievement? An exploratory study. Journal of Personnel Evaluation in Education, 20, 165 - 184.

Stronge, J.H., Ward, T, J, \& Grant, L.W. (2011). What makes good teachers good? A cross-case analysis of the connection between teacher effectiveness and student achievement. Journal of Teacher Education, 62(4), 339-355.

Taiwo, C.O. (2018). Teacher education and students' enrolment in colleges of education in Nigeria. 9th National Conference of Colleges of Education Academic Staff Union. Adeyemi College of Education, Ondo State, Nigeria, 222-230.

The American Association of Physics Teachers (2009). The Role, Education, Qualifications, and Professional Development of Secondary School Physics Teachers. College Park, MD: AAPT.

Zuzovsky, R. (2009).Teachers' qualifications and their impact on students' achievement findings from TIMMS-2003 data in Israel. IERI Monograph Series: Issues and Methodologies in Large Scale Assessment, 2, 37-62. 